\title{
Toxicity of clove essential oil and its ester eugenyl acetate against Artemia salina
}

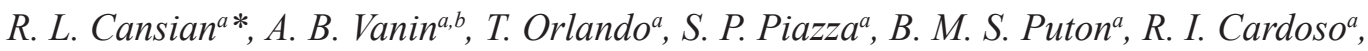 \\ I. L. Gonçalves ${ }^{a}$, T. C. Honaiser ${ }^{a}$, N. Paroul ${ }^{a}$ and D. Oliveira ${ }^{c}$
}

${ }^{a}$ Centro de Ciências Exatas, Universidade Regional Integrada do Alto Uruguai e das Missões - URI, Campus de Erechim, Av. Sete de Setembro, 1621, CEP 997700-000, Erechim, RS, Brazil

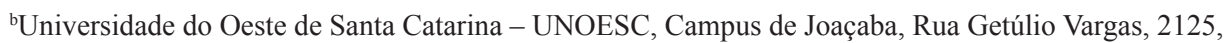
Bairro Flor da Serra, CEP 89600-000, Joaçaba, SC, Brazil

'Departamento de Engenharia Química e Engenharia de Alimentos, Universidade Federal de Santa Catarina - UFSC, CEP 88040-900, Florianópolis, SC, Brazil

*e-mail: cansian@uricer.edu.br

Received: August 11, 2015 - Accepted: December 10, 2015 - Distributed: February 28, 2017

(With 3 figures)

\begin{abstract}
The production of compounds via enzymatic esterification has great scientific and technological interest due to the several inconveniences related to acid catalysis, mainly by these systems do not fit to the concept of "green chemistry". Besides, natural products as clove oil present compounds with excellent biological potential. Bioactives compounds are often toxic at high doses. The evaluation of lethality in a less complex animal organism can be used to a monitoring simple and rapid, helping the identification of compounds with potential insecticide activity against larvae of insect vector of diseases. In this sense, the toxicity against Artemia salina of clove essential oil and its derivative eugenyl acetate obtained by enzymatic esterification using Novozym 435 as biocatalyst was evaluated. The conversion of eugenyl acetate synthesis was $95.6 \%$. The results about the evaluation of toxicity against the microcrustacean Artemia salina demonstrated that both oil $\left(\mathrm{LC}_{50}=0.5993 \mu \mathrm{g} \cdot \mathrm{mL}^{-1}\right)$ and ester $\left(\mathrm{LC}_{50}=0.1178 \mu \mathrm{g} \cdot \mathrm{mL}^{-1}\right)$ presented high toxic potential, being the eugenyl acetate almost 5 times more toxic than clove essential oil. The results reported here shows the potential of employing clove oil and eugenyl acetate in insecticide formulations.
\end{abstract}

Keywords: Novozym 435, Caryophyllus aromaticus, enzymatic esterification.

\section{Toxicidade do óleo essencial de cravo e seu éster acetato de eugenila contra Artemia salina}

\section{Resumo}

A produção de compostos via esterificação enzimática possui grande interesse científico e tecnológico devido às inúmeras inconveniências relacionadas com a catálise ácida, principalmente por estes sitemas não se adequarem ao atual termo "tecnologias limpas". Além disso, produtos naturais como o óleo de cravo, apresentam compostos com excelentes potenciais biológicos. Compostos bioativos são quase sempre tóxicos em altas doses. A avaliação da letalidade em um organismo animal menos complexo pode ser usada para um monitoramento simples e rápido, servindo também para a identificação de compostos com potencial atividade inseticida contra larvas de insetos vetores de doenças. Neste sentido, foi determinada a toxicidade frente a Artemia salina do óleo essencial de cravo e do seu derivado acetato de eugenila obtido por esterificação enzimática com lipase Novozym 435. A conversão da reação de síntese de acetato de eugenila foi de $95,6 \%$. Os resultados referentes à avaliação da toxicidade frente ao microcrustáceo Artemia salina demonstraram que tanto o óleo $\left(\mathrm{LC}_{50}=0,5993 \mu \mathrm{g} \cdot \mathrm{mL}^{-1}\right)$ quanto o éster $\left(\mathrm{LC}_{50}=0,1178 \mu \mathrm{g} \cdot \mathrm{mL}^{-1}\right)$ apresentam elevado potencial toxicológico, sendo que o éster apresenta aproximadamente 5 vezes mais toxicidade em relação ao óleo. Estes resultados demonstram o potencial emprego do óleo de cravo e de acetato de eugenila em formulações de inseticidas.

Palavras-chave: Novozym 435, Caryophyllus aromaticus, esterificação enzimática.

\section{Introduction}

The species Caryophyllus aromaticus L. belongs to the family Myrtaceae, and is commonly known as clove. The essential oil obtained from the clove is

constituted by a mixture of compounds, being the eugenol (4-alil-2-metoxyphenol) its major compound. The concentration of eugenol varies from 77-95\% (Trajano et al., 2010; 
Singh et al., 2012). The oil also presents other components of terpenes source as $\beta$-cariofilen, $\alpha$-humulen and eugenyl acetate (Chaieb et al., 2007; Dzamic et al., 2009). Eugenol has different biological properties confirmed: bactericide (Moon et al., 2011), antifungal (Rana et al., 2011), larvicidal (Pandey et al., 2013), antioxidant (Chiaradia et al., 2012; Vanin et al., 2014), anti-inflammatory (Daniel et al., 2009), among others.

Thus, the eugenol esters can also present promising biological properties. Carrasco et al. (2008) observed that eugenyl acetate presented anti-carcinogen activity in cells of prostate and oral squamous cancers. The acaricide activity of eugenyl acetate was related by Pasay et al. (2010), since eugenyl acetate presented high toxicity against human scabies mites. This compound was also described as a potent antioxidant agent by Vanin et al. (2014). The authors observed that the clove essential oil after esterification presented higher antioxidant activity compared to crude essential oil $\left(\mathrm{IC}_{50}\right.$ of $283.9 \mu \mathrm{g} \cdot \mathrm{mL}^{-1}$ and $367.5 \mu \mathrm{g} \cdot \mathrm{mL}^{-1}$, respectively).

Although they are natural compounds, both eugenol and eugenyl acetate, they can present toxicity according to the form of use, prepare and concentration. So, the care with the use is of primordial importance in the control of possible collateral and adverse effects that the chronic and/or acute use can cause on the organism.

The use of bioassays for monitoring the bioactivity of extracts, fractions and plant isolated compounds have often been incorporated into the phytochemical research. Among these biological assays it is the toxicity test with Artemia salina (BST-Brine Shrimp Test) which was developed to detect bioactive compounds in plant extracts (Meyer et al., 1982; Noldin et al., 2003). This test is a simple method in the research of natural products, which has a good correlation with tests of acute oral toxicity in vivo (Parra et al., 2001).

Literature has been presented correlations between the general toxicity with the microcrustacean Artemia salina and the citotoxicity on strains of human cells of solid tumors (Mclaughlin, 1991; Mclaughlin et al., 1998) and activity anti-Trypanosoma cruzi (Zani et al., 1995). It has been shown that there is a very good correlation between the median lethal concentrations $\left(\mathrm{LC}_{50}\right)$ of plant extracts to brine shrimp larvae and the median lethal doses $\left(\mathrm{LD}_{50}\right)$ of the same extracts, administered orally in mice (Parra et al., 2001). Besides, the essential oils with high toxic potential have been target of investigation to the production of insecticides, related to control of larvae of vectors of diseases related to public health (Leite et al., 2009). Despite described properties of eugenol and eugenyl acetate, there is a lack in the literature regarding the eugenyl acetate toxicity in A. salina.

Based on these aspects, this work aimed the production of eugenyl acetate by enzymatic esterification of clove essential oil, and the investigation of toxic potential against the microcrustacean Artemia salina of clove essential oil (Caryophyllus aromaticus) before and after the enzymatic esterification, in order to provide toxicity information for future applications thereof.

\section{Material and Methods}

\subsection{Enzymatic production of eugenyl acetate}

\subsubsection{Substrates and catalyst}

Clove essential oil (Caryoplyllus aromaticus) was purchased from Viafarma (São Paulo-Brazil) and used as substrate for enzymatic esterification. The main characteristics of the oil are presented in Table 1. Acetic anhydride (Vetec, 97\% purity) was also used as substrate and the commercial lipase from Candida antarctica (Novozym 435) immobilized on a macroporous anionic resin was donated by Novozymes Brazil (Araucária, PR, Brazil)was used as catalyst. Eugenyl acetate from Sigma-Aldrich was used as standard for product confirmation.

\subsubsection{Experimental procedure}

The production of eugenyl acetate via enzymatic esterification was carried out in the experimental condition optimized by Vanin et al. (2014). The scheme of the reaction is presented in Figure 1.

The esterification reactions were performed by preparing a reaction mixture of acetic anhydride and clove essential oil (eugenol content of $85.5 \%$ ) at molar ratio of 5:1 (90-18 $\mathrm{mmol})$ in a $50 \mathrm{~mL}$ Erlenmeyer flask.

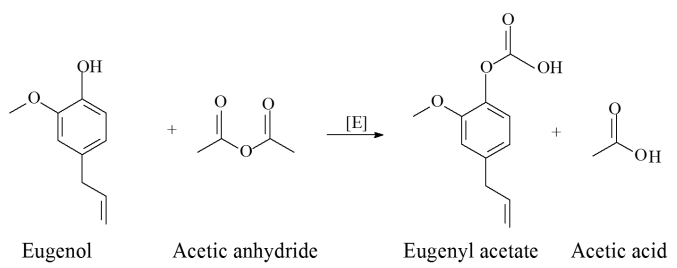

Figure 1. Synthesis of eugenyl acetate by enzymatic esterification of clove essential oil

Table 1. Characteristics of clove essential oil (Caryoplyllus aromaticus).

\begin{tabular}{lcc}
\hline \multicolumn{1}{c}{ Analysed Parameters } & Specification & Result \\
\hline Color & Light and dark yellow & Yellow \\
Density & 0.953 to $0.965 \mathrm{~g} / \mathrm{m}^{3}\left(20^{\circ} \mathrm{C}\right)$ & $0.957 \mathrm{~g} / \mathrm{m}^{3}\left(20^{\circ} \mathrm{C}\right)$ \\
Index of refraction & 1.486 to $1.498\left(20^{\circ} \mathrm{C}\right)$ & $1.489\left(20{ }^{\circ} \mathrm{C}\right)$ \\
Eugenol content* & 85.0 to $88.0 \%$ & $85.43 \%$ \\
\hline
\end{tabular}

*data from Viafarma laboratory. 
After complete dissolution of the substrates, $5.5 \mathrm{wt} \%$ of enzyme (based on the total mass of substrates) was added to the mixture. Experiments were carried out in an orbital shaker at constant agitation of $150 \mathrm{rpm}$ and $50{ }^{\circ} \mathrm{C}$. After $2 \mathrm{~h}$ of reaction, the biocatalyst was filtered and samples were kept at $5{ }^{\circ} \mathrm{C}$ for further analysis and determination of reaction conversion.

\subsubsection{Determination of reaction conversion}

Quantitative analyses of eugenyl acetate produced were carried out in a gas chromatography (Shimadzu GC-2010) equipped with data processor, using a capillary column of fused silica INOWAX $(30 \mathrm{~m}$ length $\times 250 \mu \mathrm{m}$ i.d. $\times 0.25 \mu \mathrm{m}$ thickness $)$, flame ionization detector, with the following temperature program: $40-180{ }^{\circ} \mathrm{C}\left(3{ }^{\circ} \mathrm{C} / \mathrm{min}\right), 180-230^{\circ} \mathrm{C}\left(20^{\circ} \mathrm{C} / \mathrm{min}\right)$, $230^{\circ} \mathrm{C}(20 \mathrm{~min})$, injector temperature $250{ }^{\circ} \mathrm{C}$, detector at $275^{\circ} \mathrm{C}$, injection in the mode split, ratio of split $1: 100$, $\mathrm{H}_{2}(56 \mathrm{KPa})$ as carrier gas, injected volume of $0.4 \mu \mathrm{L}$ of sample diluted in n-hexane (1:10). Reaction conversion was calculated based on the reduction of area of limitant reagent on the basis of reaction stoichiometry (Paroul et al., 2011).

\subsection{Determination of toxicity against Artemia salina}

To evaluate the toxicity of both clove essential oil and eugenyl acetate against Artemia salina, after esterification, the reaction mixture was submitted to vacuum microdistillation, to remove any residue of acetic acid and acetic anhydride from the final sample, avoiding, in this way, an incorrect interpretation of the results. In order to ensure that residual esterification products did not produced the observed response, the mortality profile of eugenyl acetate ester was assessed in parallel with eugenyl acetate commercial standard (Sigma Aldrich).

Toxicity test was carried out using the methodology described by Meyer et al. (1982) with some modifications. The cysts of Artemia salina were placed in a plastic container with artificial saline solution $(23 \mathrm{~g}$ of marine salt/1 liter of distilled/deionized water/0.7 $\mathrm{g}$ of sodium bicarbonate) with artificial illumination, under aeration, with control of temperature $\left(20-30{ }^{\circ} \mathrm{C}\right)$ during 24 hours of incubation for the hatching. After this period, the organisms-test were exposed to different concentrations of both products to be tested (clove essential oil and eugenyl acetate) for 24 hours, using test tubes, each one containing at least 10 nauplii of Artemia salina, at 10 different concentration of products, in triplicate runs. In a first assay, the range of concentration to be tested was determined $\left(10,20,30,40,50,60,70,80,90\right.$ and $\left.100 \mu \mathrm{g} \cdot \mathrm{mL}^{-1}\right)$. After, for eugenyl acetate the assay was performed with smaller concentrations. A control experiment was also carried out to be sure that mortality observed of nauplii of Artemia salina was resulting of toxicity of the compounds and not due to the restriction of food (Carballo et al., 2002). After $24 \mathrm{~h}$ of exposure, the counting of alive and dead nauplii was carried out.

The $\mathrm{LD}_{50}$ values were determined in triplicate employing non-linear regression model available in GraphPad Prism 6.0 software, and expressed as mean \pm standard deviation.
The means were compared using the $t$ test, adopting 5\% as significance level.

\section{Results and Discussion}

\subsection{Enzymatic production of eugenyl acetate}

Following the experimental condition described in the previous section (Vanin et al., 2014), the eugenyl acetate conversion was $95.6 \%$. These results are similar to other studies from the literature. Chiaradia et al. (2012) achieved a conversion of about $99 \%$ in the esterification of eugenol and acetic anhydride using a commercial immobilized lipase from Candida antarctica as catalyst, at acetic anhydride to eugenol molar ratio of $3: 1$, enzyme concentration of $5.5 \mathrm{wt} \%$ (based on the total mass of substrates), $50{ }^{\circ} \mathrm{C}$ in 6 hours of reaction. Chaibakhsh et al. (2012) synthesized eugenyl caprylate using Lipozyme TL IM as catalyst in solvent-free system, and obtained a maximum reaction yield of $72.2 \%$ at $65{ }^{\circ} \mathrm{C}, 250 \mathrm{rpm}, 100 \mathrm{mg}$ of enzyme, caprylic acid do eugenol molar ratio of $1: 2$ after 4.5 hours of reaction.

Before evaluating the toxicity of eugenyl acetate against Artemia salina, this compound was purified and its purity was confirmed by gas chromatograph, as shown in Figure 2. As we can observe, the retention time $\left(\mathrm{R}_{\mathrm{t}}\right)$ of the major compound after esterification (Figure 2c) and purification (Figure $2 \mathrm{~d})\left(\mathrm{R}_{\mathrm{t}}=25.8 \mathrm{~min}\right.$ ) corresponds to the retention time of standard eugenyl acetate (Figure 2e) $\left(\mathrm{R}_{\mathrm{t}}=25.9 \mathrm{~min}\right)$. The peaks of $\mathrm{R}_{\mathrm{t}}=8.5 \mathrm{~min}$ and $\mathrm{R}_{\mathrm{t}}=11.7 \mathrm{~min}$ correspond to the excess of acetic anhydride and acetic acid produced, respectively. A decrease of the peak of eugenol $\left(R_{t}=24.5 \mathrm{~min}\right)$ after enzymatic esterification was also observed (Figure 2a and 2c).

\subsection{Determination of toxicity against Artemia salina}

The results related to the toxicity of clove essential oil before and after esterification are presented in Table 2. The percentage of mortality increases proportionally with the concentration, reaching the maxima value of

Table 2. Mean mortality of Artemia salina according to clove essential oil and eugenyl acetate ester concentrations at $\mathrm{t}=24 \mathrm{~h}$ of exposure.

\begin{tabular}{|c|c|c|}
\hline \multirow{2}{*}{$\begin{array}{l}\text { Concentration } \\
(\mu \mathrm{g} / \mathrm{mL})\end{array}$} & \multicolumn{2}{|c|}{$\begin{array}{c}\text { Mean of dead nauplii }(\%) \pm \text { standard } \\
\text { deviation }\end{array}$} \\
\hline & Clove oil & Eugenyl acetate \\
\hline 0.0 & $0.0 \pm 0.0$ & $0.0 \pm 0.0$ \\
\hline 0.1 & $0.0 \pm 0.0$ & $37.8 \pm 3.8$ \\
\hline 0.2 & $15.0 \pm 3.1$ & $80.2 \pm 9.5$ \\
\hline 0.3 & $14.1 \pm 6.3$ & $100 \pm 0.0$ \\
\hline 0.4 & $24.9 \pm 16.3$ & $100 \pm 0.0$ \\
\hline 0.5 & $25.7 \pm 13.7$ & $100 \pm 0.0$ \\
\hline 0.6 & $53.2 \pm 14.1$ & $100 \pm 0.0$ \\
\hline 0.7 & $45.6 \pm 20.0$ & $100 \pm 0.0$ \\
\hline 0.8 & $69.7 \pm 19.8$ & $100 \pm 0.0$ \\
\hline 0.9 & $93.3 \pm 7.1$ & $100 \pm 0.0$ \\
\hline 1.0 & $100 \pm 0.0$ & $100 \pm 0.0$ \\
\hline
\end{tabular}




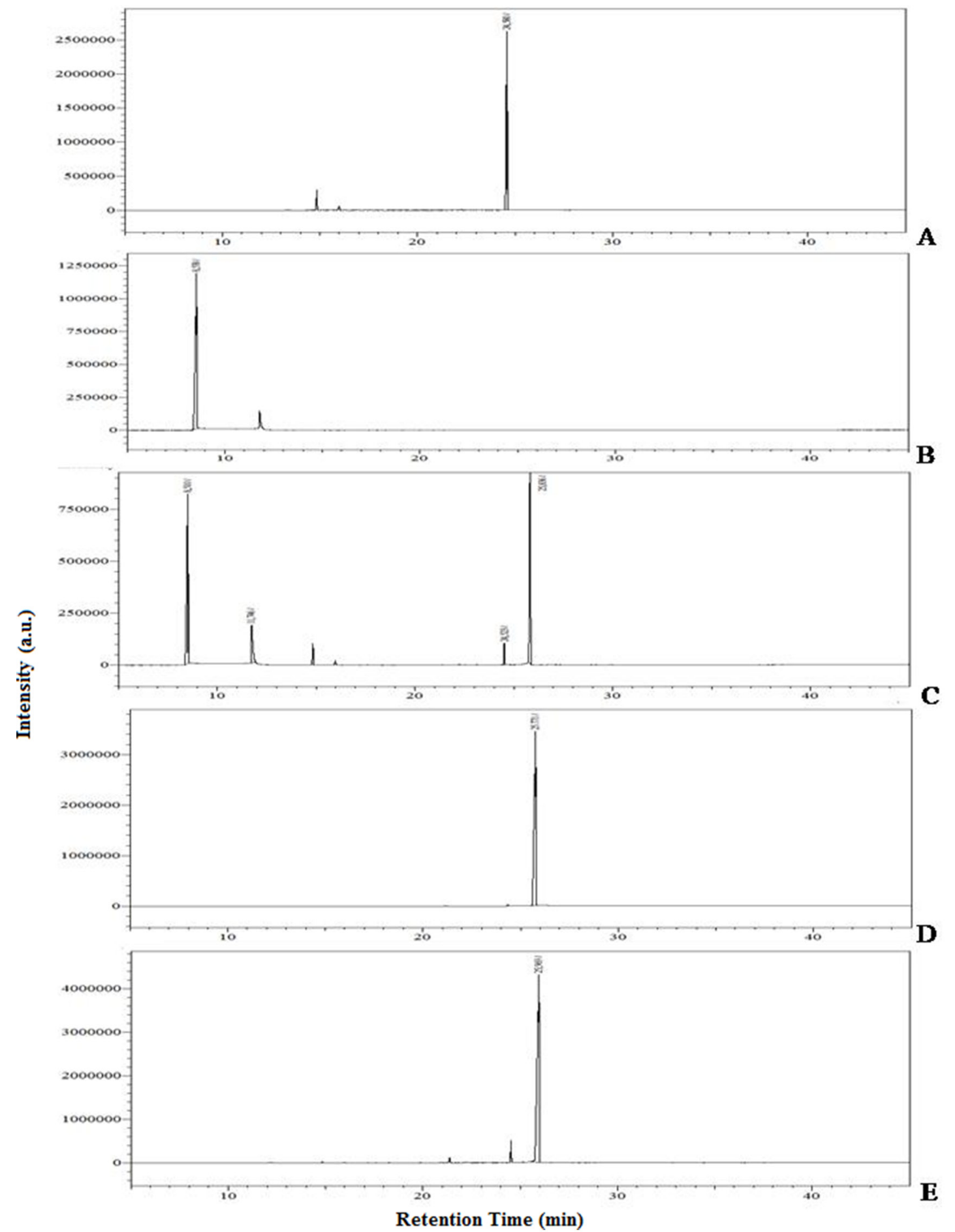

Figure 2. Chromatograms of clove essential oil (A), acetic anhydride (B), clove essential oil after enzymatic esterification (C), eugenyl acetate after purification that was used for testing with $A$. salina (D) and the standard of eugenyl acetate (E).

mortality, $100 \%$, for concentrations of $1.0 \mu \mathrm{g} \cdot \mathrm{mL}^{-1}$ and $0.3 \mu \mathrm{g} . \mathrm{mL}^{-1}$,for clove essential oil and eugenyl acetate, respectively. In absence of test substance was not observed mortality, in both cases. The correlation between the mortality with the log of clove essential oil concentration, $\log$ of eugenyl acetate concentration and log of commercial eugenyl acetate allowed to obtain the models described in Figures $3 \mathrm{a}, 3 \mathrm{~b}$ and $3 \mathrm{c}$. 

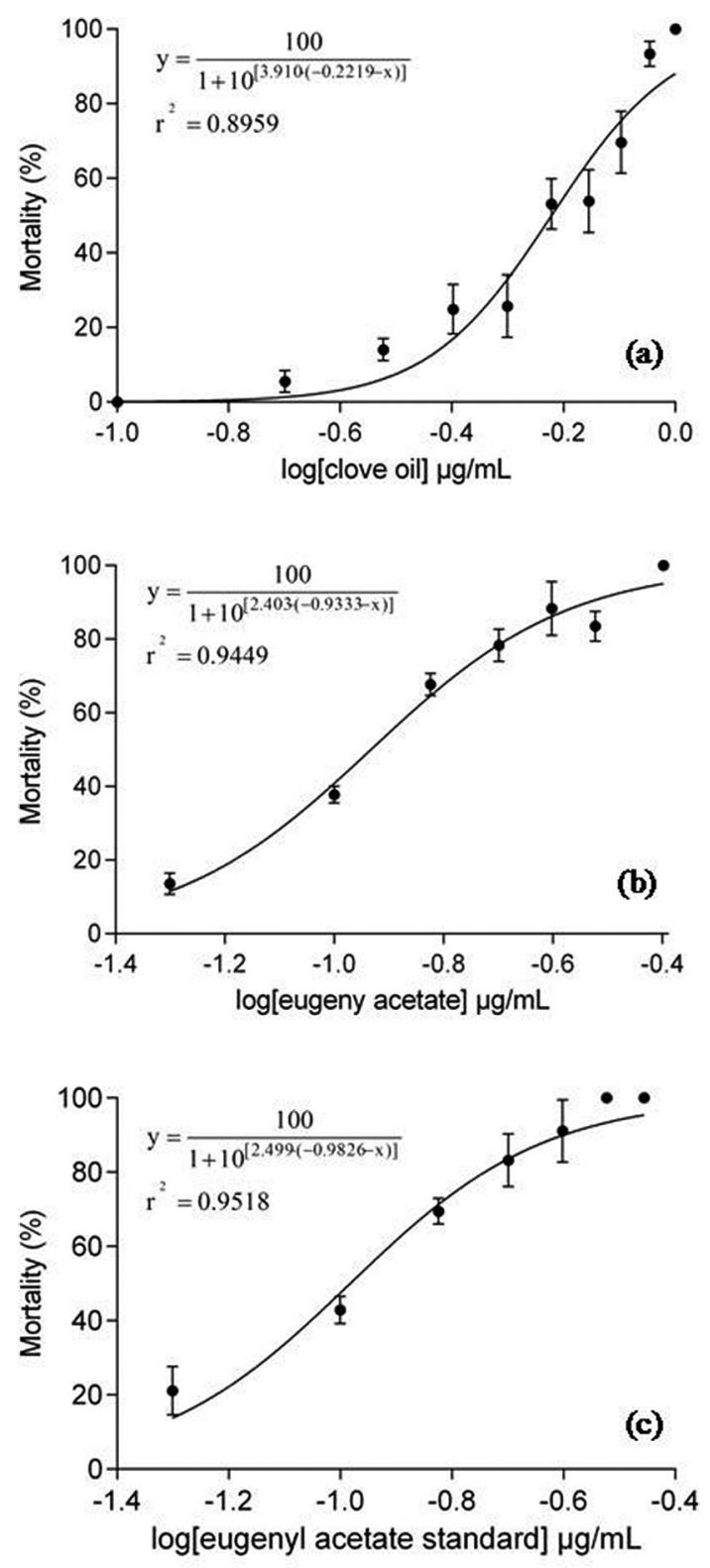

Figure 3. Toxicological effect of clove oil (a) its eugenyl acetate ester (b) and commercial eugenyl acetate (c) on A. salina.

Related to clove essential oil, the correlation between the mortality (\%) and the log of concentration of oil $\left(\mathrm{y}=100 / 1+10^{[3.910 \cdot(-0.2219-\mathrm{x})]}\right)$ with $\mathrm{R}^{2}=0.8959$ provided a value of $\mathrm{LC}_{50}$ of $0.5993 \pm 0.0464 \mu \mathrm{g} \cdot \mathrm{mL}^{-1}$. This value was similar to that obtained by Rabêlo (2010), of $1 \mu \mathrm{g} \cdot \mathrm{mL}^{-1}$ on the evaluation of toxicity of clove essential oil on Artemia salina. Rabêlo (2010) also evaluated the toxicity of eugenol and found a value of $\mathrm{LC}_{50}$ of $18.53 \mu \mathrm{g} \cdot \mathrm{mL}^{-1}$, and associated the higher toxicity of oil to the possibly synergic effect among the other compounds of the essential oil. Leite et al. (2009) found higher values of $\mathrm{LC}_{50}$ for eugenol (47.6 $\left.\mu \mathrm{g} \cdot \mathrm{mL}^{-1}\right)$.
To eugenyl acetate, obtained by enzymatic esterification and purified under vacuum microdistillation, the correlation between the mortality (\%) and the log of concentration of ester $\left(\mathrm{y}=100 / 1+10^{[2.403 .(-0.9333-\mathrm{x})]}\right)$ with $\mathrm{R}^{2}=0.9449$ gave a value of $\mathrm{LC}_{50}$ of $0.1178 \pm 0.0041 \mu \mathrm{g} \cdot \mathrm{mL}^{-1}$. We have not found works from the literature related to the larvicidal effect of eugenyl acetate against $A$. salina. Eugenyl acetate commercial standard produced a $\mathrm{LC}_{50}$ of $0.1041 \pm 0.0062 \mu \mathrm{g} \cdot \mathrm{mL}^{-1}$ $\left(y=100 / 1+10^{[2.499 \cdot(-0.9826-x)]} R^{2}=0.9518\right)$. Considering this value, the toxicological effect produced by ester obtained from enzymatic esterification was not associated with residual reaction products.

A smaller concentration of ester was necessary for produce $50 \%$ of response, if compared with clove oil $(\mathrm{p}<0.0001)$. The results analysis of $\mathrm{LC}_{50}$ before and after the enzymatic esterification, showed the increase of about 5 times after the reaction. Both concentrations found, for the oil and its ester, indicate the toxicity of the compounds. The World Health Organization reports that plant extracts showing $\mathrm{LC}_{50}<0.4 \mu \mathrm{g} \cdot \mathrm{mL}^{-1}$ has some potential to be applied as molluscicidal or larvicidal compound (WHO, 1993).

Different work have been published in the literature indicating the good larvicidal activity of essential oils on several species against $A$. salina, but with values of $\mathrm{LC}_{50}$ higher than those obtained in the present work. Oliveira et al. (2011) evaluated the effect of Pectis brevipedunculata essential oil in A. salina and obtained values of $\mathrm{LC}_{50}$ of $36 \mu \mathrm{g} \cdot \mathrm{mL}^{-1}$ for the oil extracted from the plant in natura and $19 \mu \mathrm{g} \cdot \mathrm{mL}^{-1}$ for the oil extracted from plants dried at $40^{\circ} \mathrm{C}$.

Costa et al. (2010) evaluated the extracts of different species of medicinal plants under larvae of $A$. salina based on the percentage of mortality, after $24 \mathrm{~h}$ exposure to the treatments. All species tested showed good larvicidal activity as compared to a reference compound and literature data. The extract from Vanillosmopsis arborea was the most active with an $\mathrm{LC}_{50}$ of $3.9 \mu \mathrm{g} \cdot \mathrm{mL}^{-1}$. Arcanjo et al. (2012) evaluated different medicinal plants and observed a higher larvicidal effect under $A$. salina for extracts of flowers of Acmella uliginosa $\left(\mathrm{LC}_{50}\right.$ of $\left.18.76 \mu \mathrm{g} \cdot \mathrm{mL}^{-1}\right)$.

Regarding the interesting in vitro toxicity of the assayed essential oils against $A$. salina and the importance of the diseases with larval vector in the public health, our results are promising, however it is necessary that complementary researches are performed focusing the possibility of their practical and rational application to impair the survival of the different larval etiological agent.

The enzymatic esterification of clove essential oil to the production of eugenyl acetate using Novozym 435 as catalyst showed to be a promising route to the obtainment of esters, taking into account the mild reaction conditions and the low amount of catalyst needed to conduct to high process conversion. The results obtained in this work were similar to obtained by Vanin et al. (2014), where the results of esterification of clove essential oil are better discussed. The low lethal concentrations obtained for both clove essential oil and eugenyl acetate could also indicate toxicity to other organisms such as larvae of insects vector of diseases. 


\section{Acknowledgements}

The authors thank CAPES, CNPq, FAPERGS and URIErechim by the financial support and scholarships.

\section{References}

ARCANJO, D.D., ALBUQUERQUE, A.C., MELO-NETO, B., SANTANA, L.C., MEDEIROS, M.G. and CITÓ, A., 2012. Bioactivity evaluation against Artemia salina Leach of medicinal plants used in Brazilian Northeastern folk medicine.Brazilian Journal of Biology $=$ Revista Brasileira de Biologia, vol. 72, no. 3, pp. 505-509. http://dx.doi.org/10.1590/S1519-69842012000300013. PMid:22990821.

CARBALLO, J.L., HERNÁNDEZ-INDA, Z.L., PÉREZ, P. and GARCÍA-GRÁVALOS, M.D., 2002. A comparison between two brine shrimp assays to detect in vitro cytotoxicity in marine natural products.BMC Biotechnology, vol. 2, no. 17, pp. 1-5. PMid:12270067.

CARRASCO, H.A., ESPINOZA, L.C., CARDILE, V., GALLARDO, C., CARDONA, W., LOMBARDO, L., CATALÁN, K.M., CUELLAR, M.F. and RUSSO, A., 2008. Eugenol and its synthetic analogues inhibit cell growth of human cancer cells (Part I).Journal of the Brazilian Chemical Society, vol. 19, no. 3, pp. 543-548. http:// dx.doi.org/10.1590/S0103-50532008000300024.

CHAIBAKHSH, N., BASRI, M., MOHAMED ANUAR, S.H., ABDUL RAHMAN, M.B. and REZAYEE, M., 2012. Optimization of enzymatic synthesis of eugenol ester using statistical approaches. Biocatalysis and Agricultural Biotechnology, vol. 1, no. 3, pp. 226-231. http://dx.doi.org/10.1016/j.bcab.2012.03.005.

CHAIEB, K., HAJLAOUI, H., ZMANTAR, T., KAHLA-NAKBI, A.B., ROUABHIA, M., MAHDOUANI, K. and BAKHROUF, A., 2007. The chemical composition and biological activity of clove essential oil, Eugenia caryophyllata (Syzygium aromaticum L. Myrtaceae): a short review.Phytotherapy Research, vol. 21, no. 6, pp. 501-506. http://dx.doi.org/10.1002/ptr.2124. PMid:17380552.

CHIARADIA, V., PAROUL, N., CANSIAN, R.L., JÚNIOR, C.V., DETOFOL, M.R., LERIN, L.A., OLIVEIRA, J.V. and OLIVEIRA, D., 2012. Synthesis of eugenol esters by lipasecatalyzed reaction in solvent-free system.Applied Biochemistry and Biotechnology, vol. 168, no. 4, pp. 742-751. http://dx.doi. org/10.1007/s12010-012-9814-5. PMid:22864649.

COSTA, J.G.M., CAMPOS, A.R., BRITO, S.A., PEREIRA, C.K.B., SOUZA, E.O. and RODRIGUES, F.F.G., 2010. Biological screening of araripe basin medicinal plants using Artemia salina Leach and pathogenic bacteria.Pharmacognosy Magazine, vol. 6, no. 24, pp. 331-334. http://dx.doi.org/10.4103/0973-1296.71792. PMid:21120038.

DANIEL, A.N., SARTORETTO, S.M., SCHMIDT, G., CAPARROZASSEF, S.M., BERSANI-AMADO, C.A. and CUMAN, R.K.N., 2009. Anti-inflammatory and antinociceptive activities of eugenol essential oil in experimental animal models.Revista Brasileira de Farmacognosia, vol. 19, no. 1b, pp. 212-217. http://dx.doi. org/10.1590/S0102-695X2009000200006.

DZAMIC, A., SOKOVIC, M., RISTIC, M.S., GRIJICJOVANOVIC, S., VUKOJEVIC, J. and MARIN, P.D., 2009. Chemical composition and antifungal activity of Illicium verum and Eugenia caryophyllata essential oils.Chemistry of Natural Compounds, vol. 45, no. 2, pp. 259-260. http://dx.doi.org/10.1007/ s10600-009-9283-4.
LEITE, A.M., LIMA, E.O., SOUZA, E.L., DINIZ, M.F.F., LEITE, S.P., XAVIER, A.L. and MEDEIROS, I.A., 2009. Preliminary study of the molluscicidal and larvicidal properties of some essential oils and phytochemicals from medicinal plants.Revista Brasileira de Farmacognosia, vol. 19, no. 4, pp. 842-846. http:// dx.doi.org/10.1590/S0102-695X2009000600008.

MCLAUGHLIN, J.L., 1991. Crown gall tumours on potato discs and brine shrimp lethality: two simple bioassays for higher plant screening and fractions. In: P.M. DEY and J.B. HARBONE, eds. Methods in plant biochemistry. New York: Academic Press, pp. 1-32.

MCLAUGHLIN, J.L., ROGERS, L.L. and ANDERSON, J.E., 1998. The use of biological assays to evaluate botanicals.Drug Information Journal, vol. 32, pp. 513-524.

MEYER, B., FERRIGNI, N., PUTNAM, J., JACOBSEN, L., NICHOLS, D. and MCLAUGHLIN, J., 1982. Brine Shrimp: a convenient general bioassay for active plant constituents.Journal of Medicinal Plant Research, vol. 45, no. 05, pp. 31-34. http:// dx.doi.org/10.1055/s-2007-971236.

MOON, S.E., KIM, H.Y. and CHA, J.D., 2011. Synergistic effect between clove oil and its major compounds and antibiotics against oral bacteria.Archives of Oral Biology, vol. 56, no. 9, pp. 907-916. http://dx.doi.org/10.1016/j.archoralbio.2011.02.005. PMid:21397894

NOLDIN, V.F., CECHINEL FILHO, V., MONACHE, F.D., BENASSI, J.C., CHRISTMANN, I.L., 2003. Chemical composition and biological activities of the leaves of Cynara scolymus $\mathrm{L}$. (artichoke) cultivated in Brazil.Quimica Nova, vol. 26, no. 3, pp. 331-334. http://dx.doi.org/10.1590/S0100-40422003000300008.

OLIVEIRA, M.T.R., BERBERT, P.A., MATOS, C.R.R., MATHIAS, L. and MOREIRA, R.O., 2011. Efeito da temperatura do ar de secagem sobre o teor e a composição química do óleo essencial de Pectis brevipedunculata.Química Nova, vol. 34, no. 7, pp. 1200-1204. http://dx.doi.org/10.1590/S0100-40422011000700018.

PANDEY, S.K., TANDON, S., AHMAD, A., SINGH, A.K. and TRIPATHI, A.K., 2013. Structure-activity relationships of monoterpenes and acetyl derivates against Aedes aegypti (Diptera: Culicidae) larvae.Pest Management Science, vol. 69, no. 11, pp. 1235-1238. PMid:23908002.

PAROUL, N., GRZEGOZESKI, L.P., CHIARADIA, V., TREICHEL, H., CANSIAN, R.L., OLIVEIRA, J.V. and OLIVEIRA, D., 2011. Erratum to: Solvent-free geranyl oleate production by enzymatic esterification.Bioprocess and Biosystems Engineering, vol. 34, no. 3, pp. 331-337. http://dx.doi.org/10.1007/s00449-010-0503-x. PMid:21191617.

PARRA, A.L., YHEBRA, R.S., SANDIÑAS, I.G. and BUELA, L.I., 2001. Comparative study of the assay of Artemia salina L. and the estimate of the medium letal dose $\left(\mathrm{LD}_{50}\right.$ value $)$ in mice, to determine oral acute toxicity of plant extracts.Phytomedicine, vol. 8, no. 5, pp. 395-400. http://dx.doi.org/10.1078/0944-711300044. PMid:11695884

PASAY, C., MOUNSEY, K., STEVENSON, G., DAVIS, R., ARLIAN, L., MORGAN, M., VYSZENSKI-MOHER, D., ANDREWS, K. and MCCARTHY, J., 2010. Acaricidal activity of eugenol based compounds against scabies mites.PLoS One, vol. 5, no. 8, pp. 1-9. http://dx.doi.org/10.1371/journal.pone.0012079. PMid:20711455.

RABÊLO, W.F., 2010. Caracterização química, toxicidade e avaliação da atividade antibacteriana do óleo essencial do cravo da india (Syzygium aromaticum). São Luís: Programa de 
Pós-graduação em Química, Universidade Federal do Maranhão, 77 p. Dissertação de Mestrado.

RANA, I.S., RANA, A.S. and RAJAK, R.C., 2011. Evaluation of antifungal activity in essential oil of the Syzygium aromaticum (L.) by extraction, purification and analysis of its main component eugenol.Brazilian Journal of Microbiology, vol. 42, no. 4, pp. 1269-1277. PMid:24031751.

SINGH, J., BAGHOTIA, A. and GOEL, S.P., 2012. Eugenia caryophyllata Thunberg (Family Myrtaceae): a review.International Journal of Research in Pharmaceutical and Biomedical Sciences, vol. 3, no. 4, pp. 1469-1475.

TRAJANO, V.N., LIMA, E.O., SOUZA, E.L. and TRAVASSOS, A.E.R., 2010. Inhibitory effect of the essential oil from Eugenia caryophyllata Thumb leaves on coalho cheese contaminating microorganisms.Ciência e Tecnologia de Alimentos, vol. 30, no. 4, pp. 1001-1006. http://dx.doi.org/10.1590/S0101-20612010000400025.
VANIN, A., ORLANDO, T., PIAZZA, S.P., PUTON, B.M., CANSIAN, R.L., OLIVEIRA, D. and PAROUL, N., 2014. Antimicrobial and antioxidant activities of clove essential oil and eugenyl acetate produced by enzymatic esterification.Applied Biochemistry and Biotechnology, vol. 174, no. 4, pp. 1286-1298. http://dx.doi.org/10.1007/s12010-014-1113-x. PMid:25104002.

WORLD HEALTH ORGANIZATION - WHO, 1993. Tropical Disease Research. Geneva: WHO.

ZANI, C.L., CHAVES, P.P.G., QUEIROZ, R., DE OLIVEIRA, A.B., CARDOSO, J.E., ANJOS, A.M.G. and GRANDI, T.S.M., 1995. Brine Shrimp lethality assay as a Prescreening system for anti-Trypanosoma cruzi activity.Phytomedicine, vol. 2, no. 1, pp. 47-50. http://dx.doi.org/10.1016/S0944-7113(11)80048-6. PMid:23196100. 